\title{
Development of Android Based Information System Media On Plant Diversity in Alas Purwo National Park
}

\author{
Sindi Ayu Astari ${ }^{1)}$, Imam Mudakir ${ }^{1)}$, Mochammad Iqbal ${ }^{1)}$ \\ ${ }^{1)}$ Department of Mathematics and Science Education, Study Program of Biology Education, Faculty of \\ Teacher Training and Education, University of Jember, Jember 68121, Indonesia.

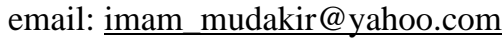

\begin{abstract}
The study aimed to develop an Android-based media information system on plant diversity in Alas Purwo National Park. This research and development study used a 4-D development model. Data collection methods used were interviews, documentation, and expert validations. The result of this study showed that the score for expert validation was $89.55 \%$ or in a very valid category. In qualitative assessment, these media need little modification, such as in the use of a source of the picture and more efficient to explain plant descriptions in the media.
\end{abstract}

Keywords: Alas Purwo National Park, System Information, Plant diversity.

\section{INTRODUCTION}

The National Park has an optimal function as the area of Conservational Education or Environmental Education intending to inform and educate the community about their natural resources and environment so that they will have some responsibility to preserve it. MacKinnon (1990) states that the most important way to study conservation is to access it directly to gain actual information. Indonesia, with its 37 National Parks, was expected to bring a significant role to the community for understanding the environment. Based on the above functions, some national parks have begun to carry out Conservation Education activities actively. With the Android-based media, people do not need to come directly to the Alas Purwo National Park to find out or see the condition and diversity of plants in the Alas Purwo National Park.

The Alas Purwo National Park is one of the Indonesian National Park. The Alas Purwo National Park is a forest area with various types of intact ecosystems on Java Island. These ecosystems are ranging from beaches (coastal forests) to lowland rainforests, mangrove forests, bamboo forests, savannahs, and industrial plantation forest. The Alas
Purwo National Park area has a high diversity of terrestrial floras with more than 700 known plant species ranging from lower-level plants to tree-level plants of various vegetation types and formations (BTNAP, 2012).

The general information about Alas Purwo National Park can be accessed via websites, brochures, leaflets, social media, or by an annual exhibition, while information about its plant diversity was less specific. The plant diversity data were only limited in the form of documents stored at the official office. Some officers of the Alas Purwo National Park are less familiar with those listed plants so that communities only have limited access about complete plant diversity information

The internet and the globalization process viewed as being the optimal frame for disseminating information that is omnipresent through the access of a smartphone. The smartphone is one of the widely used technology by people in their daily activities. Operating systems on smartphones that currently used were: Windows Mobile, Blackberry, Symbian, iPhone, Android, and others. Android is one of the most widely used OS by the public. Android is a smartphone 
operating system that is currently developing. Android has many flexibility advantages over other operating systems, in which it can be changed according to your purpose and many computer applications available for Android smartphones. The utilization of Smartphones's ability through various fields of human activities can be made by developing specific applications that can suit their use on a particular purpose. The Smartphone applications that specifically used as a learning media were called mobile learning. Mobile learning can be defined as a facility or service that provides general electronic information to education and educational content that helps the achievement of knowledge without being limited by users' location and time (Lehner et al., 2001). Also, Smartphone has high flexibility, because learning by Smartphone can be done anywhere, anytime, and can be accessed quickly by its users (McQuiggan et al., 2015).

One of the smartphones application on education purposes is developing information systems in the form of an application (apps) that contains the types of Alas Purwo National Park ecosystems to explore the plants' diversity in each ecosystem. The ecosystems in the Alas Purwo National Park are the bamboo forest, lowland tropical forest, mangrove forest, beach, savanna, and industrial plantation forest. The developed features on this smartphone application consist of identification, description, and benefits. The identification feature is the part that contains photographs and classifications of the plant. The description feature is a section that includes brief information about the plant, as well as a beneficial feature, which is a section containing the benefits of the plant on various uses. This application can be used by Alas Purwo National Park officials and the public to access information about plant diversity in Alas Purwo National Park, as well as for students to be used for reference material in learning activities.

Based on the above description, researchers participate in realizing one of the Alas Purwo National Park functions as the sustainable use of biological natural resources and their ecosystems in the form of research, science, education, cultivation support, and natural tourism by developing an Android-based information system about its plant diversity. Hopefully, this application can provide more specific information about plant diversity in Alas Purwo National Park for both the national park officials, public, and to support learning activities in Senior High School.

\section{METHOD}

This study is development research using a 4-D development model (four D model) (Farkhah, 2018). The product was an Android-based Smartphone application. The development of this application consists of four stages, namely the definition phase, design, and development. The definition stage is carried out to determine what things are needed in the development of instructional media and what obstacles occur in learning activities. The design phase is done by selecting the media and choosing a format for the developed learning media. The development phase was carried out by compiling learning media in the form of an Android-based information system, collecting assessments from experts, and revising instructional media based on advice from experts.

\section{RESULT AND DISCUSSION}

This development study using a 4D model comprising the step of defining (define), designing (design), and developing (develop) (Permatasari, 
2017). The definition stage is carried out to determine what things are needed in the development of instructional media and what obstacles occur in learning activities. The design phase is done by selecting the media and choosing a format for the developed learning media. The media and format used are adjusted to the needs of students, material, and characteristics of students. The format in this Android-based information system uses the identification system of plants in the Alas Purwo National Park ecosystem with specific information about these plants.

The development phase was carried out by compiling learning media in the form of an Android-based information system, collecting assessments from experts, and revising instructional media based on advice from experts. The validation result of the Android-based information system showed in Table 1. and Table 2.

Table 1. Result validation of Android-based Information System

\begin{tabular}{|c|c|c|c|c|c|}
\hline No. & Validator & Aspect & $\begin{array}{c}\text { Result of } \\
\text { Assessment }\end{array}$ & Result of Validation & Category \\
\hline \multirow{3}{*}{1.} & \multirow{3}{*}{$\begin{array}{l}\text { Material } \\
\text { Expert }\end{array}$} & a. Material Coverage & $100 \%$ & \multirow{3}{*}{$91.67 \%$} & \multirow{3}{*}{ Very Valid } \\
\hline & & b. Material Accuracy & $75 \%$ & & \\
\hline & & c. $\quad$ Language & $100 \%$ & & \\
\hline \multirow{4}{*}{2.} & \multirow{4}{*}{ Media Expert } & a. Ease Of Navigation, & $100 \%$ & \multirow{4}{*}{87.40} & \multirow{4}{*}{ Very Valid } \\
\hline & & b. Artistic And Aesthetic, & $85 \%$ & & \\
\hline & & c. Graphics & $81.25 \%$ & & \\
\hline & & d. Overall Functions & $83.30 \%$ & & \\
\hline \multirow{4}{*}{3.} & \multirow{4}{*}{$\begin{array}{l}\text { Development } \\
\text { Expert }\end{array}$} & a. Presentation Techniques & $100 \%$ & \multirow{4}{*}{$89.60 \%$} & \multirow{4}{*}{ Very Valid } \\
\hline & & b. Supporting Presentation & $87.50 \%$ & & \\
\hline & & c. Learning Presentation & $83.30 \%$ & & \\
\hline & & d. Presentation Components & $87.50 \%$ & & \\
\hline \multirow{3}{*}{4.} & \multirow{3}{*}{$\begin{array}{c}\text { Alas Purwo } \\
\text { National Park } \\
\text { Expert } \\
\text { Officer }\end{array}$} & a. Material Coverage & $87.50 \%$ & \multirow{3}{*}{$86.32 \%$} & \multirow{3}{*}{ Very Valid } \\
\hline & & b. Material Accuracy & $75 \%$ & & \\
\hline & & $\begin{array}{l}\text { c. Completeness Of } \\
\text { Presentation }\end{array}$ & $96.43 \%$ & & \\
\hline \multirow{6}{*}{5.} & \multirow{3}{*}{$\begin{array}{c}\text { User } \\
\text { Validation } \\
\text { (Teacher } 1 \text { ) }\end{array}$} & a. Content & $100 \%$ & \multirow{3}{*}{$94.79 \%$} & \multirow{3}{*}{ Very Valid } \\
\hline & & b. Presentation & $96.88 \%$ & & \\
\hline & & c. Overall Function & $87.50 \%$ & & \\
\hline & \multirow{3}{*}{$\begin{array}{c}\text { User } \\
\text { Validation } \\
\text { (Teacher 2) } \\
\end{array}$} & a. Content & $81.25 \%$ & \multirow{3}{*}{$87.50 \%$} & \multirow{3}{*}{ Very Valid } \\
\hline & & b. Presentation & $93.75 \%$ & & \\
\hline & & c. Overall Function & $87.50 \%$ & & \\
\hline & & Average & & $89.55 \%$ & Very Valid \\
\hline
\end{tabular}

Table 2. Suggestions and Comments from Validator

\begin{tabular}{|c|c|c|}
\hline No. & Validator & Suggestions and Comments \\
\hline 1. & Material Expert & $\begin{array}{l}\text { - The writing on the classification of plants is made more interesting } \\
\text { - Coupled with indexes for image reference, } \\
\text { description, classification, and benefits }\end{array}$ \\
\hline 2. & Media Expert & $\begin{array}{l}\text { - The description is too long, not suitable for students } \\
\text { High school because high school students need practical } \\
\text { - Expressed shorter but there is a link for } \\
\text { longer description } \\
\text { - Contacts should be added for access to the Park } \\
\text { Alas Purwo National }\end{array}$ \\
\hline 3. & Development Expert & - Need to be matched with student characteristic \\
\hline 4. & $\begin{array}{l}\text { Alas Purwo National } \\
\text { Park Expert Officer }\end{array}$ & $\begin{array}{l}\text { - There are still descriptions of plants that are empty, stay } \\
\text { just add the description }\end{array}$ \\
\hline
\end{tabular}

According to Hobri (2010), development products are said to be of high quality if they meet aspects of validity and effectiveness. Validation is a technique to assess the feasibility of product design. Experts in their field evaluate this activity. Based on input 
from experts, material and design learning that has been revised to make the product more appropriate, practical, easy to use, and has high technical quality. The results of expert validation show that the Android-based information system is categorized as very valid, with an average percentage obtained that is $89.55 \%$. Which the value of each expert validation in this media consists of a material expert is $91.67 \%$ (very valid), for media experts is $87.4 \%$ (very valid), development expert is $89.6 \%$ (very valid), whereas Alas Purwo National Park expert officer $86.31 \%$ (very valid). The validation carried out by the users. Namely, two high school teachers categorized as highly accurate, with the validation value of each teacher, one user being $92.71 \%$, and second users are $87.5 \%$. Information system validator suggestions and comments Androidbased can be used with revisions. Qualitative data in the form of ideas and comments are then used as reference material to make revisions to the Android-based information developed. Information system revision results based on Android-based on suggestions and comments from the validator can be seen in Table 3.

Table 3. Results of Android-Based Information System Revision Before Revision After Revision

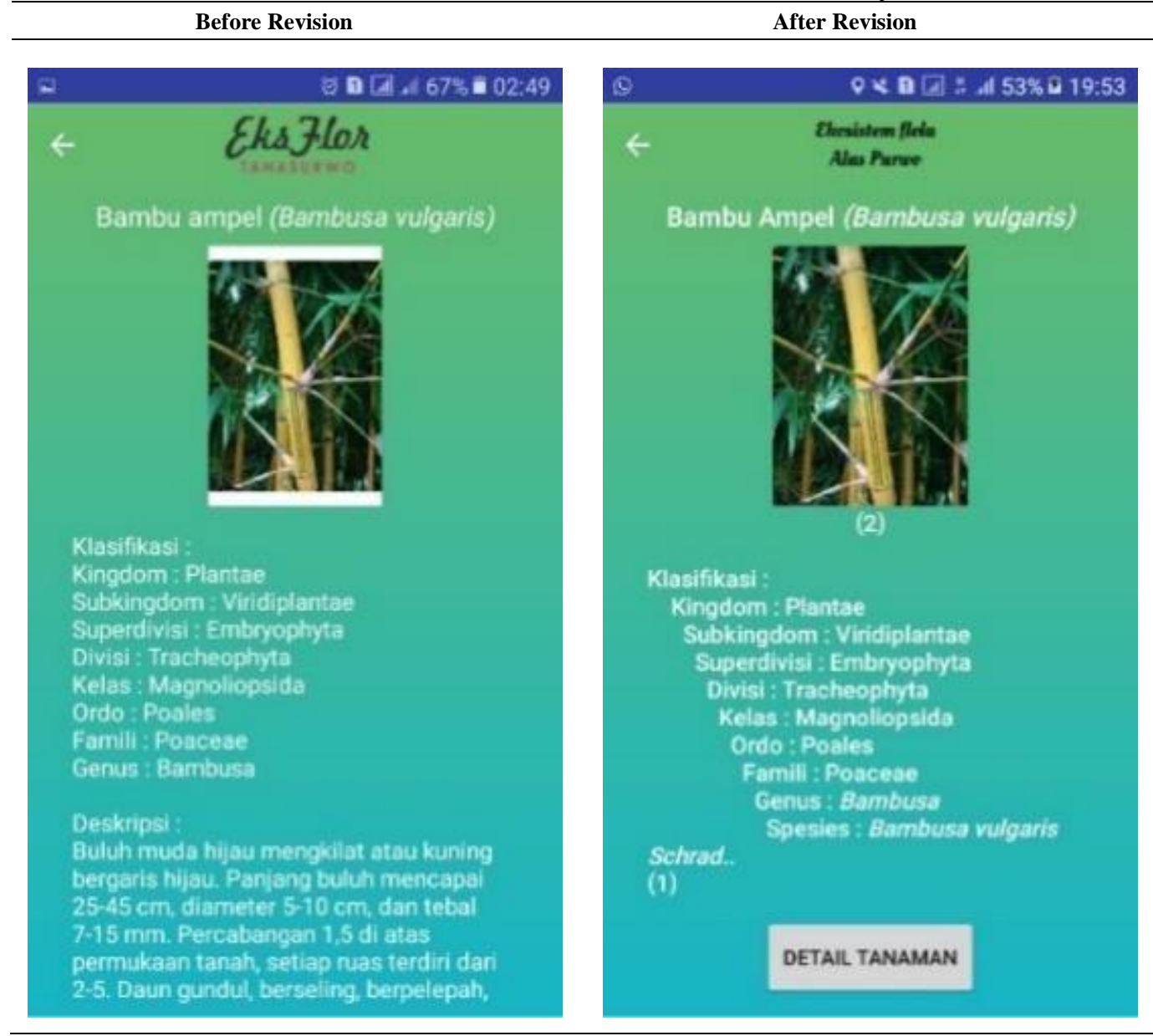

\section{CONCLUSION}

Android-based information system media that has been developed based on the results of validation is very valid for use with an average percentage of validation results of $89.55 \%$ 


\section{REFERENCE}

Alas Purwo National Park Office. 2012.

Research Information Book

[Online]. tnalaspurwo.org [18

November 2017].

Farkhah, SN, W, Subchan, and M, Iqbal. 2018. Development of Interactive Multimedia on The Subject of the Nervous System for Students Grade XI of Senior High School. Bioeducation Journal. XVI (2).

Hobri. 2010. Metodologi Pengembangan. Jember: Pena Salsabila

Lehner, F., Nosekabel, H., And Lehmann, H. 2001. Wireless ELearning and Communication Environment: Welcome to the University of Regensburg [Online].
http://SunSite.Informatik.RWTHAachen.de/Publications/CEURWS//Vol-61/paper2.pdf [May 21, 2017].

Mackinnon, J and K, Phillipps. 1990. Birds on Java and Bali . Yogyakarta: Gadjah Mada University Press.

McQuiggan, S., L, Kosturko., J, McQuiggan, and J, Sabourin. 2015. Mobile Learning: A Handbook for Developers, Educators, and Learners. New Jersey: John Wiley \& Sons, Inc.

Permatasari, EA., I, Mudakir, and K, Fikri. 2017. Development of Adobe Flash-based E-Modules in The Reproductive System Topic For IX Class MIPA Senior High School. Saintifika Journal. 19(1). 